\section{Trade and industry}

\author{
Stephen Hancocks OBE \\ Editor-in-Chief
}

Send your comments to the

Editor-in-chief,

British Dental Journal

64 Wimpole Street,

London,

W1G 8YS

Email bdj@bda.org
I am not sure whether it is peculiar to the UK but we do seem to place a lot of store in the meaning and importance of names and titles. Even the words 'names' and 'titles' have a panoply of hierarchies and nuances embedded in various avenues of our culture.

So, a discussion point for you. What is the difference between trade and industry? I pose the question because the organisation currently known to us all as the British Dental Trade Association (BDTA) has declared that there is a difference and that as of 1 January 2014 it will be changing its name to the British Dental Industry Association (BDIA). As Chief Executive Tony Reed said at the press conference to announce the change, it will take many years before we get used to using the new acronym especially when referring to what will now be their annual BDIA Showcase exhibition; but the shift is needed.

The Association has decided to make the change to reflect developments in its member base in recent years which in turn is a product of the myriad movements in technology, business practice and of course dental practice which have descended upon us and modified many of the activities that we undertake on a daily basis. Over $20 \%$ of the BDTA's current member companies are now involved in business, financial and publishing services and so it seems that 'industry' better speaks to the overall thrust of their endeavours.

\section{DIVERSITY AND CONSOLIDATION}

Victorian society was notorious for looking down its collective nose at 'trade' as being somehow grubby and not to be associated with. The existence of tradesmen's entrances says it all. I have nevertheless thought for a long time that the epithet 'dental trade' somehow undervalues the huge contribution that our colleagues and partners make to our ... our what? How do we define the dental world in which we live and operate? If it is not a trade then is it an industry? Would we prefer to dub it a profession? I suspect so. Yet as I have argued here for some years, a true profession is one which is self-governing, which we no longer are since our regulatory body, the General Dental Council, is appointed by a government body and no longer elected by ourselves. Are we then a business? Certainly we are in business. Or are we all, as the over selfconscious non-discriminatory international parlance has it, healthcare workers? Certainly we all work. But none of these descriptors quite manages to capture the essence of what we do, or how we see ourselves. Maybe though there is a deeper problem, perhaps we don't quite know how we see ourselves. On the one hand, yes we are professionals but we are also business people; we do provide healthcare but we also have to make a living; we are caught up in an industry and yet we seek to rise above the seeming coarseness that an industrial process implies.

So should we diversify more or consolidate more? Should we form one huge association that encompasses all our interests and represents all of our aspirations? This is probably not the solution as there are many activities that we carry out which members of the BDT(I)A do not and cannot. Similarly, we rely on them for the equipment and services to allow us to take care of our patients and which we could not begin to develop, manufacture or supply.

That said, we would be foolish to deny that the boundaries are blurring. With the advent of direct access for the public to DCPs our role is no longer as clear cut as it used to be. In the pilot schemes for the new NHS dental contract the importance of the computer software to drive the patients' oral health assessments is key. In many ways one sees how the BDT(I)A's thinking has been influenced. There are countless examples in our wider worlds too, particular in retailing where the imperative to survive is a constant source of diversity and innovation. It is now quite unthinkable that garages only sell petrol and diesel. What began as sidelines in sales of logs, kindling, flowers and daily newspapers has now burgeoned into such roadside convenience facilities being grocer's shops, mini-supermarkets and even snack bars. Garden centres which once sold only things that grew in the earth now resemble rural department stores replete with furniture, greetings cards, antiques and delicatessens. Supermarkets have hit back by stocking clothes, household goods, petrol, plants...oh, and including dental practices...the circle is almost complete.

The decision by the BDT(I)A is therefore a timely and interesting one. In changing only one word in its title it is actually if not heralding then certainly reflecting a change in the way in which we need to think, plan and act in order to stay ahead in our chosen profession, business or industry. Names and titles may on the surface seem to be only of passing value in that they identify people, organisations or places in order that one can then proceed to engage with them further. Greater analysis suggests that when carefully chosen they can prove to convey a good deal more than first anticipated.

DOI: 10.1038/sj.bdj.2013.1099 